\title{
Context and Content: Harold Innis, Marshall McLuhan, and George Grant and the Role of Technology in Modern Society
}

\section{Philip Massolin}

ABSTRACT: Social science and science grew significantly in Canadian universities during and after World War Il. This growth, along with a growth in consumerism and mass culture, signalled the decline of the centrality of the humanities in the curricula of Canadian universities and the rise of the technological society. Harold Innis, Marshall McLuhan, and George Grant were leading critics of this trend. Their criticism was shaped by the home front experience of Canada during World War II and the economic boom which followed the war. Although not linked through friendships, professional collaboration, or common academic disciplines, their thoughts and criticisms of technology and mass culture were shaped in a context which they shared.

Since the first half of the nineteenth century the forces of mechanization and industrialization have elicited detailed critiques from intellectuals, which seemed to have intensified in this century. In mid-twentieth century Canadathere emerged an articulate appraisal of the modemizing role of technology. Harold Innis, Marshall McLuhan, and George Grant became concerned, even obsessed, with the nature and effects of technology on cultural and social development in Canada and elsewhere in the Western world. Although not linked through friendships, professional collaborations, or common academic disciplines, the three scholars came together intellectually in their focus on technique as vital to social and cultural evolution. Through their recognition and articulation of the role of technology in a changing world they formed the foremost group of "technological critics" in Canada. As such, they made a significant intellectual contribution through their efforts to understand technique as a key aspect of the process of modemization. 
Rather than solely linking their thoughts and insights, a chief objective of this analysis is to place the ideas of Innis, Grant, and McLuhan into historical and intellectual contexts. ${ }^{1}$ While their social observations were limited in terms of their impact on Canadian academia, they were significant because of the insights they provided into larger philosophical questions of modernity. In a seeming paradox, concerns about the modernization of Canada shed light on the development of both conservative and liberal thought in Canada during the 1940 s and 1950s. Innis, McLuhan, and Grant were strongly linked intellectually to the past, not only in that they studied technology's impact from a historical point of view, but also because they wanted to preserve values and outlooks of former times and ensure the perseverance of intellectual and social traditions into the future. They agreed with the basic Burkean precept that progress is achievable only in reference to past successes; advancement, in other words, relied on the slow, but inexorable building on past accomplishments, physical, moral, philosophical, and intellectual. Their ideal social conception indeed looked as much to the past as it did to the present and the future. Yet the three social observers can also be considered liberals. Their greatest indictment of technique was that it denied humanity's freedom to act and think in accordance with its true nature. The most pernicious effect of modern technology, they endeavoured to demonstrate, was that it created false perceptions and expectations about the world while it effectively obscured key philosophic and moralistic underpinnings of westem civilization. For them, technology was an illiberal, even tyrannical force. In large measure, their social critiques were efforts to point out this lamentable reality.

Most studies of the so-called "Tory mind" in the Canadian context concentrate on the pre-1914 period. ${ }^{2}$ Very little has been accomplished regarding Canadian intellectual conservatism after 1945 , although for the same period there has been a great deal of study of the conservative movement in the United States. This essay endeavours to contribute a statement on an aspect of conservatism in mid- 
twentieth-century that is only cursorily dealt with in Canadian historiography. And while much more attention has been devoted to the liberal frame of reference of Canadian intellectuals, Innis, McLuhan, and Grant have rarely been incorporated into the body of historical literature on liberal thought. ${ }^{3}$ This paper is limited, however, to a discussion of the response to technology as an aspect in the ideological orientation of Canadian scholars, and therefore cannot provide definitive answers as to the nature of liberal and conservative thought in Canada.

In spite of the characterization of the Great War as a symbolic rupture of Canadian and western society, after 1918 Canadian academics continued to focus on ways to improve society and foster socio-cultural development. In a word, the period between the wars was still one in which "academic liberalism" prevailed. " Despite naysayers such as political economist Harold Innis, such intellectuals as W.A. MacIntosh, O.D. Skelton, Adam Shortt, and A.R.M. Lower, along with forward-looking academic socialists such as Frank Underhill (and others involved in the League for Social Reconstruction and later the Cooperative Commonwealth Federation), formed the most prominent grouping of Canadian intellectuals. The prevailing attitude among these academics was that, in spite all of its deficiencies, society was repairable, largely through the application of reform-liberal principles and the use of the state as a positive instrument to remedy economic problems and generally to foster social justice. ${ }^{5}$ The understanding that society was evolving, indeed ameliorating, a view characteristic of the pre-1914 era, persisted well into the twentieth century.

Canadian intellectuals, moreover, seemed to forget the wider, "civilizational" implications of the Great War and instead turned their attention to addressing problems at hand. The period between the wars evidenced the growing importance of the university scholar as "expert," not merely in his own academic field, but increasingly as a source of information and advice for government bureaucrats and the public at large. The 1920s and 
1930s saw the emergence of a new group of civil servants who brought with them into government socialscientific training and theories of social management and government intervention. ${ }^{6}$ Many academics who were used to the cloistered surroundings of the academy now became involved in governmental policy making. They sat on boards, became royal commissioners, took part in official surveys, and provided expert testimony for committees.' The roots of what historian Doug Owram has called the "government generation" of Canadian scholars were taking hold.

But while the 1930 s constituted a reprieve in the scholarly reassessment of western civilization, the Second World War, like the Great War, led to a renewed questioning of society. With the outbreak of war, intellectuals wanted to know how western civilization had failed to learn the lessons of the first conflict and embroiled itself yet again in total war. As in the post-World War I period, moreover, academics realized that the war constituted a great rift in the fabric of western culture, for more was at stake than lives and the survival of political units; the very values and ideals of western civilization had come under siege. This "profound disturbance" entailed, for instance, the seeming erosion of liberal and democratic principles. E.J. Urwick wrote to fellow political economist and friend Harold Innis in late 1940 to express his thoughts on the nature of democracy that Canada and the Commonwealth had gone to war to protect:

We talk of war aims, and the new order after the war-of democracy and liberty and really free enterprise. But do the people in charge, from Churchill downwards, ever want anything except manipulated democracy (government of the people by a few of the people for the benefit of some groups of the people, with the deluded consent of many of the people), and liberty incorporated in the hands of the privileged, but with freedom unlimited for the enterprising grabbers and determined keepers of humanity's best goods? 
Innis, for his part, agreed with Urwick's assessment of the demise of modern democracy. He expressed his objections regarding the current state of democracy "on the homefront" in responding to the government's censure of colleague Frank Underhill. In 1941, University of Toronto officials and the Ontario legislature threatened to dismiss Underhill for wartime statements which they believed to be offensive and contrary to the cause of prosecuting the war. ${ }^{9}$ Despite "crossing swords" with Underhill on various occasions, ${ }^{10}$ Innis felt obliged to defend a colleague. Along with other scholars, he petitioned the president of the university. In an impassioned plea to the president, heavy with symbolic references to both his and Underhill's service in the Great War, Innis warned:

If the proposals regarding Professor Underhill are carried out, our task is hopeless and whether we like it or not we encourage the growth in beliefs in class struggle and foster the movements with which we believe democratic civilizations are at present threatened. I venture to think that the issue with which we are concerned is of far reaching vital importance-larger than any one of us, larger than this institution-a part of the liberal democratic civilization itself. I am profoundly convinced that once the Board of Governors understands this, once the legislature understands this, the immediate issue becomes of paltry significance. Can the University make a contribution to this war by dismissing a veteran of the last?"1

To Innis, the Underhill affair made clear the battle scholars engaged in to ensure the university's freedom from increasing governmental controls. But it represented far more than the censure and possible dismissal of a colleague; it had far reaching significance in terms of not only academic freedoms, but also freedoms within a supposed liberal-democratic society, locked in a death struggle with totalitarian regimes. For Innis the restriction of academic freedoms was a disturbing manifestation of the decline of individual liberties and the growth of statism. Most of all, it was a example of the usurpation of additional power by the central authorities of 
the "westem democracies" readily justifiable in a time of war. To Innis and several of his colleagues, including E.J. Urwick and Donald Creighton, the talk of war aims and of a new order after the war, sensitive to the needs of democracy, was really merely a smoke screen which obscured the realities of increased governmental controls and a manipulated democracy concerned with government by the few for the few and privileged. ${ }^{12}$ With the resort to force and militarism during the war, Innis argued, society was unable to uphold the principles of freedom and democracy. "We have resorted to force rather than persuasion," he wrote in 1944 , "and to bullets rather than ballots."13

Even worse than the increasingly illiberal atmosphere of wartime were governmental efforts to deceive and propagandize the population into thinking that it contributed to the preservation of a free and democratic society. Through the vehicle of public opinion, Innis asserted, government officials attempted to appeal to "slogans in the interest of mass support."14 In this rabble-rousing climate, toleration and respect disappeared and the "demagoguery of politicians" took over. Through the aid of the press, nationalist rhetoric intensified and destroyed internationalism and the capacity for toleration and restraint. Ironically to Innis, the rhetoric of politicians and propaganda machines "educating" against the evils of Hitlerism contributed to the development of an illiberal, even fascist-like state at home. To be sure, Innis loathed the emergence of a state in which power and control were pervasive features, allowing no room for counterbalancing forces to offset an increasing intolerant, undemocratic polity. Canada, as a democratic, pluralistic, and tolerant nation, was in severe peril.

Similar concerns had emerged among other Canadian intellectuals about the impact of the war to challenge liberal-democracy in Canada through the imposition of governmental controls. There was a sense that the war was an end-point; the rise in totalitarianism and atrocities of war were associated with the advent of a new controloriented age. In a 1941 Canadian Historical Review 
article, for instance, historian Arthur Lower wrote that the war had resulted in a "vast increase in the edifice of control" over all aspects of life; "... at present," he indicated, "we have a very complete degree of politica] control: control of opinion, of personal freedom, assembly, organization, movement, and residence, and no great reverence for due process of law." "The innumerable boards and commissions thrown up by the war", he continued, were responsible for "establishing mechanisms" to increase state control over the individual. The War Measures Act, moreover, "a law which bestows complete and absolute power upon the dominion government," was the main tool by which the state gained power over its citizens. Wartime restrictions on personal liberties signalled the emergence of a "new kind of state" "based upon control." The "unresolved problem", he concluded, was whether the type of state was to "permit a free enquiry." Fellow historian Donald Creighton shared Lower's concerns. In 1944, Creighton showed that,

the war appear[ed] to have revealed certain unexpected weaknesses in the foundation of free speculation in Western society; and the present intensification of political power, as well as the vast extension of planning, may suggest other impending difficulties for the future. ${ }^{16}$

Like Innis and Lower, Creighton thought that wartime controls had gone too far, so much so, in fact, that "the permanent values" were "somewhat distorted, minimized, or overlooked in wartime ..." The philosopher George Grant took an even more moralistic and indeed fatalistic point of view. On the eve of war he wrote to his mother, "War is becoming more supreme. Evil is completely predominant if you look anywhere. Force is being used on every side and everyone is hopelessly lost. Perhaps (although this is impossible for any government) force should be given up ..."18 Thus, to several observers, the war seemed a turning point, one in which force and 
control by the governments of the democracies rivalled the illiberality of the fascist regimes abroad.

These musings about the advent of the control-oriented state were not simply empty rhetoric. Canada had indeed become extraordinarily centralized as a result of the war. In addition to such overt measures as the War Measures Act (WMA), ${ }^{19}$ rationing, the regulation of wartime materials, and price controls, the federal government regulated businesses and labour, ${ }^{20}$ increased taxes, imposed controls on foreign exchange transactions, and gained control over the corporate and income-tax areas from the provinces (under Wartime Tax Agreements, 1941), among a litany of other control measures. Ottawa, moreover, employed an army of civil servants to administrate the new powers. Numbering 46,000 in 1939 , the bureaucracy more than doubled to 116,000 by 1945. ${ }^{21}$ Crown corporations were established to acquire war materiel such as silk, uranium, and fuels, while they also ran such diverse enterprises as airplane factories and telephone companies. ${ }^{22}$

Wartime controls, however, did not disappear at the cessation of hostilities. Most noticeably, clothing and food items such as butter, meat, and preserves continued to be rationed, and it took some time before the federal government restored taxation and other powers to the provinces. "Reconstruction" and "planning," became watch words in post-war government and bureaucratic circles. Beginning in late 1943, it became clear that the central government would remain involved in keys areas of social and economic planning. Resting on the fear of the resumption of the Depression and the need to provide comprehensive social programs, the Liberal government endeavoured to continue wartime powers emanating from the WMA into the post-war period. Culminating in the Dominion-Provincial Conference on Reconstruction (commencing August 1945), the federal government presented a plan to endow the central government with the financial power and legislative authority to guide Canada through further social and economic uncertainty. Despite the charges of dissenting provinces that dominion 
proposals were akin to the work of Hitler or Mussolini, the central government continued to collect income, succession, and corporate taxes into the late 1940s and 1950 s. ${ }^{23}$ And although national health schemes died on the bargaining table, the federal government was determined to proceed with programs that did not require provincial cooperation. Apart from the reconstruction conference, the federal government enacted legislation in 1944 and 1945 to administer demobilization grants to war veterans in such sundry fields as education, business development, and agriculture, while it also enacted housing legislation, previously an area of provincial jurisdiction. While many in government circles lamented that reconstruction measures had not gone far enough, especially in the area of social policy, it was clear that the government was successful in extending such centralizing policies after 1945.

Innis and others regarded the Second World War not only in terms of the corruption of political principles, the enlargement of bureaucratic controls, and resultant abuses of free expression, but also as a period characterized by a decay in morals and values. Scholars' perceptions of profound change in the moral composition of western societies of the 1940 s were related to a perceived decline in philosophical values. Nowhere was this decline more evident than in Canadian higher education. While faculties of arts had influenced the course of higher learning since the nineteenth century through to the $1930 \mathrm{~s}$, when increasing numbers of "experts" emerged in social sciences departments, the 1940s evidenced an important transition in Canadian academia. Responding to the exigencies of modern warfare, government and military officials turned to the universities to provide trained scientists, engineers, and health-care personnel. Indeed, the 1940 s was a key phase in growth of the sciences and medicine in Canadian universities.

But, while the universities' newfound emphasis on the sciences raised their profile and increased their prestige 
among the population at large, some considered the change of priorities irksome. ${ }^{24}$ Innis, for instance, in an article revealingly entitled "A Plea for The University Tradition," remarked that from the nineteenth century the western university had succumbed to new trends in the sciences and mathematics and as a consequence became less and less respectful of its traditions in the humanities and liberal arts. In responding to the demands of the military and the government, he continued, the university fell away even further from its old beliefs and yielded to the tendencies of "bureaucracy and dictatorship." 25 Later, Grant added his voice to Innis's: "Can it be doubted that Canadian universities today exist essentially as technical schools for the training of specialists?" Even humanistic disciplines such as history, classics, and European literature were treated as technical subjects with no regard for "the sweep of our spiritual tradition." Institutions of higher learning could scarcely be called "universities," in Grant's opinion, given the preponderance of technical disciplines and the highly specialized nature of modern scholarship. ${ }^{26}$ Critics of the modern university feared that the neglect of the humanities meant that the university as a focal point for cultural study verged on collapse. To Innis, the modern university "no longer represent[ed] civilization." What remained of the ancient academy, Innis lamented, was "besieged on all hands by villains."27

Many scholars, moreover, responded to the assertion that the humanities were outmoded. They argued instead that humanistic values were central not only to the university, but also to society at lange. In The Humanities in Canada, Watson Kirkconnell and A.S.P. Woodhouse reported that humanists were in "the midst of a movement that [was] reacting against excessive preoccupation with techniques divorced from humanizing influences ...." Kirkconnell and Woodhouse discovered scholars disliked trends towards dehumanized scholarship and advocated instead a return to the humanist learning of the premodern university. They asserted that association with poets, orators, and historians 
detached the academic "from the mere present, humanized his imagination and elevated his sentiments." Humanistic learning was a means of escaping the corrupted values inherent in the modern world and promoting the appreciation of the "full measure of humanity" that had been lost. Further, the humanities cultivated the ethical and moral awareness of the individual. For Kirkconnell and Woodhouse, a liberal education was essential in modern times rife with the perversity of war, for it embodied moral values of goodness and beauty and confronted "the terror and cruelty of [the] contemporary world." Scholars extolling the benefits of a humanistic education thought that the reemphasis of humanistic learning and values was the only remedy for an unstable, uncertain world and a community seemingly indifferent to age-old scholarly traditions. ${ }^{28}$

In addition to reemphasizing humanistic values, scholars also advocated a "philosophical approach" to the problems of modern civilization. This approach deviated from other scholarly analyses of society in that it was not value-free; it entailed instead a profound philosophical critique of the foundations of the modern world, especially material conditions emerging in Canada in the 1940s. With total war came massive material requirements in terms of industrial and natural resources. There was therefore a great need for engineers, and industrial technicians of all kinds to direct the war effort on the home front. The clamour for trained scientists, engineers, and health-care professionals by government and military meant that disciplines of practical value, that is, those that had been deemed necessary to fight the war, rose in size and stature within university communities throughout the early 1940s. Indeed, a "culture of utility" had grown up around the modern university that emphasized the utilitarian role of knowledge in important practical endeavours such as achieving victory in war and in the construction and improvement of society into the postwar age. ${ }^{29}$ Against this backdrop, the contemplative, philosophical understanding of society - an intellectual effort to escape 
both the narrow focuses of the natural and social sciences - waned in a country preoccupied with solving immediate material and economic needs. Nevertheless, adherents to the philosophic approach preached the rejection of academic specialization and advocated instead a quasi-interdisciplinary contemplation of current and historical cultural conditions. In particular, history, in combination with philosophy, economics, and classics, was used in this scholarly methodology to understand how the past interacted with the present and how the traditions and wisdom of former cultures impinged upon modern circumstances. In examining the conditions of past cultures, moreover, it was believed scholars could see a time and place unaffected by modern circumstances and therefore assess the development of the modern society. Through this approach, analysts could escape current biases and contemporary tendencies to understand the present from narrow perspectives and provide instead an assessment of society, balanced by an understanding of western cultural traditions.

C.N. Cochrane's Christianity and Classical Culture (1940) was for several the best example in Canada of the use of the philosophical approach. ${ }^{30}$ "To read the work," George Grant wrote,

is to understand that the history of the ancient world has been illustrated for him in the predicaments of his own society, and that he uses the example of the ancient world to throw his light towards the solution of modern predicaments. Clearly, what he says about Greece and Rome has been wrought in the furnace of what he has seen in his own civilization .... ${ }^{31}$

Innis concurred. Indicating the value of Cochrane's study to modern social scientific research, he declared that

the significance of the volume for social scientists is in its philosophical approach. In classical civilization reason 
asserted its supremacy and in doing so betrayed its insecure position with disastrous results .... The sweep of the Platonic state in the nineteenth and twentieth centuries and the spread of science has been followed by the horrors of the Platonic state. The social scientist is asked to check his course and to indicate his role in western civilization. His answer must stand the test of the philosophic approach of Cochrane. ${ }^{32}$

For both Grant and Innis, Cochrane's book was a model for scholars to follow since it provided the example of how to overcome tendencies towards specialization and the other vices of modern scholarship. In a scholarly community that had lost its way it represented a rekindling of the contemplative tradition of the university. Indeed, it was an example for academics of the type of scholarship they should imitate, an example which Innis, Grant, and even McLuhan (in his early career) followed in their critiques of modern, technological society.

Rebuking the progressive, nineteenth-century view of technology, in which technological advancement was largely viewed as a way to improve the lot of humankind, the Canadian critics of technology viewed technological change as a profoundly influential agent of social change. Innis, Grant, and McLuhan perceived technology not in terms of being an objective tool to be exploited by humans to better material conditions and ease the basic struggle for survival; instead they treated technology as the all-pervasive factor of the modern condition, altering social organizations and human interactions as well as one's perceptions of the world. To the critics of technology, it was the root cause for the contemporary crisis in values, both moral and scholarly, and therefore its analysis and its role in society was vital to understanding modern society.

Harold Innis had always been concerned with the part technology played in effecting historical change. From his 
earliest writings on the Canadian Pacific Railway to The Bias of Communication (1951), the common thread tying his thought together was the function of technology - whether it be transportation, industrial machinery, or communication media to alter economic relationships and influence societies, institutions, and cultures..$^{33}$ But while Innis emphasized the vital role of technology to historical and social change through the latter half of his scholarly career, technologies of communication achieved paramountcy as agents of change by the 1940 s. Indeed, communication technologies displaced the economic staple as the main force of change in Innis's theory.

Against the backdrop of tremendous change he perceived existed during the Second World War-the intrusion of government into academic and civilian life, the decline of liberal-democratic principles, and the general decay of morality and ethics of western societies-Innis turned to a study of technology for an understanding of a corrupted culture. To simplify, his basic premise was that the means of communicating information rather than the information conveyed was an essential factor in determining the nature of western civilizations. Communications technologies became important to study for Innis precisely because they intervened more than any other form of technology in the structuring of political and economic relationships. He argued that each particular culture or civilization throughout the history of the West was organized in accordance with the qualities and values associated with the notions of space or time and that this spatial or temporal orientation constituted the "media bias" of the culture in question. If a civilization's chief means of communication were spatially-biased, for instance, such as paper, or the printing press, then the society's social and political organization would also be concerned with spatial characteristics, such as the maintenance of imperial control over vast reaches of geographical space. Similarly, if the dominant form of communication was a durable medium, such as stone tablets, or even the spoken 
word, the social organization of the culture under study would reflect a temporal bias, as in a religiously-oriented culture with time-biased institutions (churches). The dominant form of communication, in short, strongly influenced social organizations, institutions, and cultural attributes of society. ${ }^{34}$

Another fundamental premise of Innis's theory was that advances in communication technology were the main determinants of change. Since communication media shaped social and political organizations, a change in the means of communication entailed a change in the very make-up of the civilization. Throughout the history of the west, Innis showed how time-based cultures, such as Hellenic Greece, eventually gave way to spatially-oriented civilizations, such as the Roman Empire, which, in turn, became the basis for medieval Europe, all in accordance with the dictates of changing forms of communication technology. Similarly, spatially-biased modern society had emerged from medieval civilization due to the advent of the printing press. He demonstrated, in brief, how the historical process was characterized by the replacement of one set of media-influenced conditions - the monopoly of knowledge - with another, usually of the opposite nature. This shift in bias was cyclical in nature in that spatial or temporal "empires" rose and fell over and over again, rarely existing in a relationship in which spatial and temporal forces balanced each other off.

Whereas civilizations invariably decayed with the introduction of new communications media, mid-twentieth century society was anomalous in that new media strengthened rather than weakened the existing monopoly of knowledge. To Innis, the most troublesome effect of modern communications media - the newspaper, radio and television, among others - was that they oriented cultural and political institutions solely in terms of spatial qualities. This overemphasis of the concept of space meant that "temporal" values - the moral, the sacred, and the appreciation of the past-were beginning to disappear. The result was that modem humans, who had historically apprehended their social 
surroundings in relation to the interplay between the forces of space and time, could only view their world in terms of spatial concerns - i.e., the preoccupation with the present, the future, the technological and the secular. Recent technological innovations in the field of communications effectively destroyed temporal cultural values and replaced them with spatial values. "The Western community," Innis argued, referring to the printing press's impact on the technical-social relationships of the twentieth century, "was atomized by the pulverizing effects of the application of the machine industry to communication." "The overwhelming pressure of mechanization evident in the newspaper and the magazine", he would later add,

led to the creation of vast monopolies of communication. Their entrenched positions involve a continuous, systematic, [and] ruthless destruction of elements of permanence [i.e., the values associated with duration] essential to cultural activity. The emphasis on change is [now, with the advent of modern communications technology,] the only permanent character. ${ }^{36}$

Innis lamented that technology, in the form of communications media, reduced humanity's appreciation of time and tradition. The emergence of the new spatial monopoly created a paradox. Change, which pervaded modern industrial society and was reflected by the "great disturbance" of total war, became the lone "value" moderns could consider lasting. Clearly, for Innis, modern media were responsible for westerners "present-mindedness" and their "obsession with the current."

Nowhere was the tendency of modern technology to distort perception and to overemphasize spatial values to the exclusion of their temporal counterparts more evident than in the modem academic's understanding of his societal condition. Innis thought that print technology influenced modem Western civilization to such an extent that an appraisal of the functioning of media bias throughout the centuries became extremely difficult to undertake. Innis asserted that, 
The significance of a basic medium to its civilization is difficult to appraise since the means of appraisal are influenced by the media, and indeed the fact of appraisal appears to be peculiar to certain types of media. A change in the type of medium implies a change in the type of appraisal and hence makes it difficult for one civilization to understand another. ${ }^{37}$

In other words, Innis argued that communication media's impact on each historical period distorted the analyst's perceptions and understanding about the world in which he lived. Because the academic fell prey to the effects of his own socio-technical circumstances it became difficult for him to understand the true nature of the media bias of his own time. Scholars were inextricably bound to the intellectual and cultural environment which the prevailing media bias fostered. "Media relativism" marred the intellectual's effort to comprehend past societies and the latter's relationship with the modern age, since the scholar superimposed the values and attributes of his own culture on the civilization under study. "[I]n using other cultures as mirrors in which we may see our own culture," Innis averred, "we are affected by the astigma of our own eyesight and the defects of the mirror, with the result that we are apt to see nothing in other cultures but the virtues of our own." "38 Thus, modern scholars suffered from the acute deficiency of being unable to appraise their own culture for what it was: a civilization with its own biases, its own distinct means of socio-political organization, and its own patterns of information transfer. The modern intellectual, Innis argued, was thus "perhaps too much a part of the civilization which followed the spread of the printing industry to be able to detect its characteristics." 39

In spite of this pessimism, Innis still advocated the necessity of understanding the true character of the media bias. He argued that despite the all-pervasiveness of the machine bias, an appreciation of modern culture in light of the realities of the past enabled the historian to compare societies which were different in their media 
composition. He believed that through the study of historical ages which escaped the effects of industrialism and machine bias the scholar could better understand the problems and implications of twentieth century culture. In so doing, the scholar could appraise how spatially-or temporally-oriented patterns of thought interacted and how, more generally, western society reached its current state. "Unbiased" history was the key to the scholar's understanding of society and his efforts to alter the impact of modern technology. He pleaded with his contemporaries to expose the current media bias and begin to comprehend its effects so that they could preserve the values and traditions had come under attack. For Innis, then, the role of the scholar was to take the first steps to enlighten society as to the pervasive, distorting qualities of communications media. Innis wrote:

Immediately we [modern scholars] venture on this inquiry [that is, an analysis of the media bias], we are compelled to recognize the bias of the period in which we work .... The bias of modern civilization incidental to the newspaper and the radio presume a perspective in consideration of civilizations dominated by other media. We can do little more than urge that we must be continually alert to the implications of this bias and perhaps hope that consideration of the implications of other media to other civilizations may enable us to see more clearly the bias of our own. ${ }^{40}$

In sum, the effect of technology on society was at the very core of Innis's critique of modern civilization. Technological change, in the guise of advances in communication media, was the root cause of the formation of monopolies of knowledge, the most recent of which threatened the destruction of western values and institutions.

Marshall McLuhan, the literary critic turned communications theorist, also put forth a view of technology's impact on 
modern civilization. Through a long and often controversial academic tenure, McLuhan, like Innis before him, studied the role of technological advances and, specifically, new communications media, as critical factors affecting modern social development. Although scholars have acknowledged McLuhan's contributions as a media theorist during the height of his scholarly career in the 1950s and 1960s, there is little study of his social critique during the 1940 s and early 1950s. Hence, there is little sense of how McLuhan's pre-Innisian views emerged. An effort is made here to trace the early development of McLuhan's critique of the technological society.

For McLuhan, as well as Innis, the 1940s was a formative decade in the development of his concept of technology. In this period McLuhan turned his attention away from literary studies and focused instead on a critique of the role of technology in society. In a world shocked by the tragedies of Nazi science and atrocities of atomic and conventional weaponry, it is not surprising he began to concern himself with humanist values and the juxtaposition of these values with those of an increasingly inhuman world. Specifically, McLuhan, along with many others, became embroiled in the continent-wide debate over the merits of "technical" education, a debate that had raged for years in the United States but only recently had come to the fore in Canada.

John Maynard Hutchins, chancellor and former president of the University of Chicago and staunch advocate of humanistic education, held considerable influence among Canadian intellectuals and made a special impact on McLuhan. ${ }^{41}$ McLuhan, a humanist himself, appreciated Hutchins's humanism and his critique of the trend within universities towards technical education. For McLuhan, Hutchins stood for the Ciceronian ideal: education was designed to produce citizens with a wide learning, alert to social problems. ${ }^{42}$ Through his efforts to present humanist alternatives to an increasingly lessthan-human era McLuhan truly reflected the "Catholic 
humanist" orientation that characterized his early intellectual development. ${ }^{43}$

While Hutchins's humanism was more than palatable, however, McLuhan found Hutchins's educational approach unsatisfactory. Hutchins's approach was incomplete because it overemphasized the study of literary classics while ignoring an "unofficial program of education" "carried on by commerce through the press, radio, and movies." Only through a study and critique of "unofficial education" could the scholar comprehend the "native and spontaneous culture in our industrial world" and, moreover, "effect contact with past cultures." 45 The study of the "Greats" was only "part of the solution"; 46 it had to be supplemented with a study of modern culture. For McLuhan, only by gaining insight into one's own culture could one become conversant with cultures of the past. ${ }^{47}$ True to his own credo, McLuhan set about understanding the unofficial education of contemporary culture. ${ }^{48}$

The "early McLuhan," like Harold Innis, thought that shifts in technique were critical to cultural development. Providing a moralistic appraisal of technology, he echoed Innis in warning that technological change was at the core of the corruption of western values. Writing at the end of the war McLuhan demonstrated the influence of technology to standardize human outlooks. In the form of print media, technology's most profound effect in modern society was the creation of "the common man," the unification of humanity through a common desire for consumer products. Modern advertising, a salient factor in the emergence of common man,established witticisms, symbols and behaviour patterns, and a common language of discourse; it provided, in other words, a shared experience. Advertising also altered existing perceptions of reality to accord with advertising strategies. "The adman's rhetoric," McLuhan declared, "has knocked the public into a kind of groggy, slap-happy condition" in which "are cushioned" the "brutal shocks" of social realities. As evidence of this confused condition, McLuhan argued that freedom for North Americans did not necessarily 
mean free and just government; rather, freedom consisted, according the advertising ethos, largely "in ignoring politics and worrying [instead] about defeating underarm odour, scaly scalps, hairy legs, ... [and] saggy breasts ..."' educating humans as to what to eat, how to look, and what to do, print media advertising fostered a standardized, "commercial culture." Above all, it was a means of totalitarian control, a way for advertising executives and others to engineer society, and, in a more insidious fashion, a way to alter perceptions and divert attention from pressing problems..$^{50} \mathrm{McLuhan}$ thus echoed Innis's strictures on the pervasiveness of the control-oriented nature of the modern world.

For McLuhan, commercial culture concealed the more cerebral needs of humankind. Reducing humanity to its "lowest common denominator as consuming animal," technology thwarted rightful pursuits such as the cultivation of speech and culture, and, most significantly, the acquisition of the "heritage of our entire civilization." 51 Nevertheless, McLuhan implored moderns to contemplate the humanistic virtues of literature and other artistic endeavours so as to establish a "sense of communion, and wisdom for the common race" and to regain a sense of true humanity which preceded the machine. ${ }^{52}$ Indeed, his early strictures such as The Mechanical Bride: Folklore of Industrial Man (1950) were efforts to understand the processes by which "the very considerable currents and pressures [have been] set up around us today by the mechanical agencies of the press, radio, movies and advertising." 33 Only in accepting the existence and effect of contemporary social forces, he reasoned, could intellectuals comprehend new realities with a view to overcoming them. In this way, moderns could realize the homogenizing, standardizing force of the machine and begin to come to terms with "Time, Life, and Fortune" and other "sinister portents" in the "Century of the Common Man." 54

In The Mechanical Bride, McLuhan further developed his assessment of the cultural role of technology. Technology 
redefined human relations not only between individuals but also to industrial society. Through advertising, it created a new, servomechanistic relationship, in which man became servant and technology controlled the nature and pace of modem life. Technology was both invasive and enslaving, for, while it affected every aspect of existence, moderns neither understood nor cared about the effects of machine culture. McLuhan wrote:

A huge passivity has settled on industrial society. For people carried about in mechanical vehicles, earning their living by waiting on machines, listening much of the waking day to canned music, watching packaged movie entertainment and capsulated news, for such people it would require an exceptional degree of awareness and an especial heroism of effort to be anything but supine consumers of processed goods. ${ }^{\text {ss }}$

Through consumer conformity, technology, in its many guises, robbed humans of their individuality and freedom to understand the world. ${ }^{56}$ It was an "abstract tyrant" that carried its "ravages into deeper recesses of the psyche than did [for primitive humans] the sabre-tooth tiger or the grizzly bear."'s7

For McLuhan technology was also responsible for profound social change. He argued that technology meant "constant social revolution." ${ }^{\text {"In }}$ the recent past, for instance, the two world wars "led to an unimaginable acceleration of every phase of technology-especially advancing the universal social revolution which is the inevitable result of the impact of machines on human rhythms and social patterns." 59 Although McLuhan failed to explain the interplay between technological and social transition-his early studies were not much more than observations of the societal impact of technology-he was certain that technological advance implied a speedup of social change. Further, he contended that the acceleration of technology was so pronounced in the recent past and humanity so profoundly altered by 
technological change that humans existed in a "trancelike condition," unable to appreciate the social effects of technology. Unlike prior "social revolutions," where humans could at least identify the nature and impetus of social change, the mid-twentieth century was so mired in the conformity of consumerism and other manifestations of modem technology that social realities were extremely difficult to comprehend. Because modern life was becoming increasingly a "technological rather than a social affair," there were no more "remote and easy perspectives." Hence, there was no means of understanding reality except by comprehending the all-pervasive role of technology. Humankind, he concluded, was embroiled in a "technological nightmare," from which the only hope of escaping was to be aware of the pervasive effects of the machine on modern society. ${ }^{60}$

Although lacking the same sophistication, McLuhan's view of "technology as tyrant" echoed Innis's monopoly of knowledge concept and his position on the inherent illiberal effects of modem technology. It reflected an Orwellian world view in which "Big Brother" used technology to create a totalitarian existence. The presence of dismal accounts of the fate of humanity in the machine age are not difficult to reconcile in a world in which the horrors of past totalitarian regimes were still fresh, and in which new political tyrannies seemed to be rising everywhere.

McLuhan's critique of technology perhaps most of all mirrored a post-war society concerned more with consumerism and consumption than with external realities. The post-war decades were ones of great material prosperity for North America. Not only had Canada escaped the ravages of another economic downturn, it had emerged from the war with a vibrant consumer economy. Aided by intense and sophisticated ad campaigns, "materialism," in a word, become a deeply imbued social ethic ..." in post-war Canadian society. ${ }^{61}$

While many Canadians basked in the warm glow of material prosperity, by the late 1940 s there began a strong reaction against the increasingly material and secular outlook of 
Canadians. Vincent Massey, as chancellor of the University of Toronto, addressed this issue in numerous speeches. Massey noted that growth in the "matters of mind and of the spirit" were the most significant aspects of national development. Furthermore, he hoped that material advancement would be "matched by knowledge and wisdom"; that Canada, in other words, would be characterized as much by intellectual and artistic accomplishments as by economic prowess. ${ }^{2}$ For Massey, materialism had been overemphasized at the expense of the intellect, contemplation, and the other-worldly. He thought that the most significant evidence of the decline of spiritual values existed in the "crisis of the humanities": the sundering of the humanities and the rise to prominence of the pure and applied sciences. The sundering of the humanistic and philosophic tradition was the direct result of the rise to prominence of the applied and pure sciences. ${ }^{63}$

In an unpublished paper in late 1949, Innis also questioned the advent of post-war materialism. Innis, like Massey, criticized this pervasive materialism. His primary focus was to study the reasons for which western society had come to have such a "high regard for material things." ${ }^{\text {"4 }}$ Established as a "universal value in the nineteenth century," he argued that materialism in North America had increased its scope through the aid of advertising and the media in this century and due to the availability of resources. Exacerbated by the media and commercialism, the ever-increasing concem with materialism presented modern humanity with a grave problem: the consumer orientation of society had developed to such an extent that it had become "impossible [for moderns] to stop demanding new resources. ${ }^{\circ 5}$ Most importantly, materialism was such a part of the modern ethos that it threatened the existence of non-material values. Materialism, in other words, had become so much a part of the western psyche that a concern for opposite values - tradition, beauty, and spirituality -were being lost. Innis's admitted obsession with the values of "time" responded to an age increasingly characterized by the drive towards material acquisition and resource exploitation. ${ }^{66}$ 
Of the critiques of the impact of materialism in post-war Canada, George Parkin Grant's was one of the most detailed and profoundly thought out. Grant, Massey's nephew, had picked up his disdain for industrial life during his time in England, where he saw first-hand the ravages of a long-lived industrial system. His grandfather, George Munro Grant, had greatly influenced his perception of materialism and industrial development. Writing around the turn of the century, G.M. Grant acknowledged the great strides Canada had made economically, but he questioned whether too great an emphasis had been placed on economic development to the detriment of spiritual values. He wondered whether Canada was to be a "city of pigs" or a "a land of high-souled men and women?"6? The elder Grant concluded that due to a "vulgar and insolent materialism of thought and life" Canada had lost its moral focus and had been reduced to a consuming, unreflective mass of humanity. ${ }^{68}$ So akin to G.P. Grant's social philosophy and so relevant to the ongoing struggle between matters of the mind and the material world, the elder Grant's comments could easily have been uttered a half a century later and attributed to his grandson.

More than his grandfather, his uncle, or any other critic of materialism, George Parkin Grant couched his critique of the material world in terms of secularization. The almost obsessive concern with things material, Grant contended, resulted ultimately in a turn away from the otherworldly. Ironically, this concern for materialism for Grant had its roots in puritan protestantism. Characteristic of protestantism in North America, Grant argued that Calvinism had originally promoted piety and biblical truth, but over time, "it destroyed its own spirit." Intended to marry the secular and the other-worldly, the reformist spirit eventually lost a sense of the transcendent. As it did so, it began to "take the world ever more as an end in itself." "As the Protestant vision of the Kingdom of God 
on Earth declined, there only remained the idea that humanity can change the world for the better. Shorn of its religiosity and its focus on the afterlife, the resilient elements of the reformed Protestant tradition were more akin to hedonism than the melding of the secular and religious. Lamentably for Grant, the materialism of mid-twentieth century English Canada was in large the product of the secularization of reformed Christianity.

The most pernicious effect of this secularization was the advancement of a new concept of freedom. In "The Uses of Freedom", Grant explained that the basic concept of freedom in the reformed tradition - the introduction of the truth of God and Christ in the lives of humans - had been transformed into a different notion: simply, "the ability to change the world" without reference to Christian beliefs." In secular terms, people could now achieve liberty by controlling their physical environment rather than achieving liberation or freedom by means of communion with God. To control the physical environment meant to open up new areas of human endeavour. Thus, for Grant, freedom was defined in technical and material rather than in spiritual terms. $^{72}$

Essential to the liberal-secularist concept of freedom was the instrumental role of science and technology to gain mastery over nature. For Grant, perhaps the most important epistemological change in the westem world was that scientific knowledge, which taught "one how to change the world," displaced Christianity as "true knowledge." important element in exploiting natural resources and securing material growth, moreover, was a change in attitudes towards science and technology. Technical or scientific knowledge, Grant explained, was not to be pursued for the pleasure of the mind; it was not an end in itself, but instead merely an instrument to be used first to understand nature and then gain a measure of control over it.

Grant realized how technique after Bacon became integral in the world-view and values of modern humanity. Moderns, he would later argue, defined themselves in relation to technological and scientific advances. Grant 
argued that "technique comes forth and is sustained in our vision of ourselves as creative freedom, making ourselves and conquering the chaos of an indifferent world."74 Modern life was thus founded on the "technological myth," the idea that "man has finally come of age in the evolutionary process" in that "he has taken fate into his own hands and is freeing himself for happiness against the old necessities of hunger and disease and overwork ...."7s Indeed, modern society's ultimate "good," the moral conception upon which philosophy in the mass age was based, was the freedom which technological progress engendered.

Moderns not only identified themselves in terms of technical achievement and the freedom it produced, but they also propagated the means for the advancement of technical knowledge. ${ }^{76} \mathrm{Like}$ Innis and others, Grant attributed the rise of technical training in higher education to the perceived needs of government and industry. He realized early on in his academic career that, in terms of funding and recognition, the humanities were neglected in comparison to the sciences. Most significantly, he objected to the ongoing preference to examine the physical sciences over "the study of the deeper questions of human existence." "7 Grant observed that the philosophic understanding of the good life

... simply for its own sake was neglected as archaic. To see the world in its wholeness, was the equivalent to many of seeing the progress in our mechanical inventiveness. The more Canada has become part of the scientific society of the west, the more it has partaken of the ideas such as these, and the tragedy of its youth has been that the bond of tradition have been less strong with us than elsewhere. ${ }^{78}$

Writing in 1950, Grant claimed that "mass industrialism" promoted certain ideals that had an "almost incalculable spiritual change in the west." ${ }^{.79}$ Most importantly, moderns exalted materialistic over contemplative values, a life of action over one of thought and reflection. Like any pioneering country, Canada, to Grant, had been predisposed to 
materialism. For Canadians, the comfort and control gained through technological advances resulted in great appreciation of material progress and, most dangerously, a commensurate predisposition to ignore the virtues of philosophic contemplation. ${ }^{80}$

Despite efforts to understand the philosophic malaise of the modern west, ${ }^{81}$ the "mass world" ultimately had forsaken non-utilitarian, philosophic knowledge. Even philosophers themselves who had been historically entrusted to discover the good and God's purpose in the world fell prey to the new technological ethic. Philosophers, according to Grant, abrogated their responsibility as social critics and moral leaders of the community. In expounding on positivistic and pragmatic theories, and in separating philosophy and theology, Canadian philosophers, like their counterparts elsewhere, partook "in making philosophy the servant rather than the judge of man's scientific abilities." ${ }^{22}$ In becoming a "technical study," philosophy, like other humanistic disciplines, forgot its historic origins and succumbed to the dictates of the masses. The teaching of philosophy in Canada contributed to the development of universities as "technical institutes," and, as such, reflected the effects of technological liberalism on the modern world.

Like several of his contemporaries, George Grant lamented the centrality of technology in modern lives. In defining "what we are" he argued that technology alienated the individual from his true self because it reduced his higher, philosophical goals to the mere objective of obtaining technological freedom. Consequently, people became servants to the machine. They lacked true freedom precisely because the pursuit of technology became their "dominant activity" so much so in fact that it curtailed the pursuit of other societal "goods." ${ }^{33}$ Grant wrote that

every instrument of mass culture [was] a pressure alienating the individual from himself as a free being .... The individual [became] ... an object to be administered by scientific efficiency experts.... Modern culture, through movies, 
newspapers and television, through commercialized recreation and popular advertising, force[d] the individual into the service of the capitalist system around him. ${ }^{84}$

Grant also objected to the way in which modern technology controlled an individual's understanding of himself and of his historical circumstances. His most important criticism was that the highest truth in the mass age-freedom achieved through technique's conquering of human and non-human environments-was perceived as the sole truth. The individual was therefore restricted in what he could think or believe, since technology itself limited the terms by which the world could be understood. Grant asserted that

the drive to the universal and homogeneous state remains the dominant ethical ideal to which our contemporary society appeals for meaning in its activity. In its terms, society legitimizes itself to itself. Therefore any contemporary man must try to think the truth of this core of political liberalism, if he is to know what it is to live in this world. ${ }^{85}$

Rediscovery of the contemplative and philosophic traditions was, for Grant, the only way to counteract the ever-increasing effects of the technological imperative. He advocated the rekindling of humanistic values such as individual moral awareness, an appreciation of the arts, and a contemplative, imaginative life. Further, he implored modern humanity, in their search for meaning, to return to the foundations of western thought, Greek philosophy and Christianity, and abandon all remnants of technological liberalism. This reversion to principles inherent in Greek and Christian philosophy would provide the necessary counterweight to the "pure will to technique" characteristic of the modern age. ${ }^{86}$ In returning to these primal forces, people could recover eternal truths, escape their current "technologically induced" view of the world, and, hence, realize their true nature: unity to God and the "good life." 
The philosophical malaise characteristic of modern technological society and the crisis of values to which Grant and others referred were reflected in a growing movement concerned with Canada's cultural development. In many ways, these perceptions about Canadian cultural development were products of a larger intellectual milieu that became increasingly uncomfortable with such traits of modern mass culture as wanton materialism, consumerism, in addition to the unfettered devotion to science and technology. Specifically, they were products of the environment that gave rise to the so-called Massey Commission.

Originally proposed immediately prior to the Liberal's national convention of 1948, the Royal Commission on National Development in the Arts, Letters and Sciences, chaired by Vincent Massey, began work the following year. The Massey Commission had been appointed to investigate broadcasting, federal cultural institutions, governmental relations with voluntary cultural associations, and federal university scholarships. But it also had a broader, selfdefined agenda. The commission took it upon itself to examine and define Canadian culture. It parleyed the quite narrow terms of reference into a crusade for Canadian cultural nationalism. ${ }^{87}$ The Massey commissioners accomplished these unstated objectives in part by showing how Canadians differed from Americans; how they had, in the past, resisted "American" trends towards mass culture and related attributes such as commercialism, consumerism, and anti-intellectualism. "Americanization" was used in a pejorative sense and came to mean the corruption of longstanding Canadian cultural traditions while at the same time it emphasized the distinctiveness of Canada in North America. They opposed, above all, the triumph of "lowbrow" or "mass" culture because cultural Americanization meant the loss of an independent and indeed superior Canadian cultural identity.$^{88}$ In the broadest sense, the Commissioners endeavoured to underscore the existence of a Canadian 
cultural crisis. They wanted to show Canadians how mass culture eroded spiritual traditions and therefore undermined the foundations of Canada's cultural inheritance. The commission's focus on intellectual and cultural "nourishment" was an effort to alert Canadians on the need to alter cultural orientations away from current trends and towards the preservation of time-honoured traditions..$^{89}$ The antiAmerican bias of the Massey commissioners and others belonging to the so-called cultural elite reflected the postwar cultural milieu in Canada. Their "anti-American" nationalism very much reflected the rise of the so-called American empire through the technology of mass culture.

The Massey commissioners, and other cultural nationalists, were more than alarmists who opposed mass culture in all its forms. Rather, they were a part of a group interested in national cultural development and became known as the culture lobby. ${ }^{90}$ The Massey Commission was the official, governmental recognition of the long-term efforts of lobbyists to raise public awareness of cultural issues. Its establishment reflected a sympathetic national mood in postwar Canada."

Not Massey commissioners themselves, Innis, Grant, ${ }^{92}$ and McLuhan like the commissioners, expounded on a cultural "crisis" in postwar Canada. These scholars suggested that Canada had become a culturally impoverished nation due to the over-emphasis on things scientific, technological, and material. They showed that cultural values and institutions, such as the university, were in eclipse, because of the pervasiveness of machine culture. Above all, their writings were attempts to educate on the need to balance modem cultural trends against the traditions of bygone civilizations, to balance science and technology with a renewed concern with humanistic values. If not cultural lobbyists per se, then, Innis, Grant, and McLuhan were members of a cultural elite, who, like the Massey commissioners, identified profound defects with modern culture, and whose self-imposed responsibility it was to alert unsuspecting Canadians to the realities of a technological age. As university scholars, they endeavoured 
to influence outlooks and mould opinions of those around them and, hopefully, the public at large. Like the cultural nationalists, they wanted to see their pronouncements become relevant to the larger issues of Canadian national development.

To conclude, there were several factors that bring together the writings of Innis, McLuhan, and Grant on technology. First of all, the content of the views of these three social critics were context to their scholarly and historical environments. For Innis, World War II accelerated change and accentuated the cultural malaise created by a machine age culture. Similarly, the crass materialization and commercialization of Canadian society impressed Grant and McLuhan to question the direction of their society. All three scholars operated in a scholarly environment that, while more receptive than ever before to technical education, was increasinly suspicious of the value of the humanities. In brief, they wanted to make sense out of a world that otherwise would allow the triumph of scientific values over humanistic values, a society that seemed to have lost touch with the traditions and values of the past.

In the decades after World War II, Innis, McLuhan, and Grant converged intellectually in their identification of technology as a vital force determining the nature of the modern world. Their efforts to focus on modern problems such as the decline of the university, the decay in morals, and the corruption of western society at large, fits into this analysis. Through Innis's theory of media bias, Grant's critique of technological liberalism, and the early McLuhan's concept of the servomechanistic relationship between humans and machines, each scholar demonstrated a concern for the moral demise of Western civilization. They all believed that the modern age was different than any other that came before it precisely because the all-pervasive quality of technique undermined the moral quality of Western culture. In fundamentally altering social structures and the individual's ability to find understanding in a changing social milieu, they implicitly agreed that 
technology profoundly affected the traditional philosophical and ethical foundations of society. They were all keenly aware of the qualities of modern technology to alter social relations and corrupt traditional values and hence were drawn together intellectually in their scholarly devotion to understanding the impact of technology on the modern world.

*The author wishes to acknowledge the invaluable assistance that the two anonymous referees and editors have provided in revising this article. Any errors or omissions are the responsibility of the author.

'Arthur Kroker studies the intellectual interrelationships of the three critics of technology. Yet he does not place their thought within its historical context. See Arthur Kroker, Technology and the Canadian Mind: Innis, McLuhan, and Grant (Montreal: New World Perspectives, 1984).

2See David Mills The Idea of Loyalty in Upper Canada, 1784-1850 (Kingston: McGill-Queen's University Press,, 1988) and A.B. McKillop, A Disciplined Intelligence: Critical Enquiry into Canadian Thought in the Victorian Era (Montreal: McGill-Queen's University Press, 1979).

'Barry Ferguson's recent work is the most prominent example of the study of so-called liberal intellectuals of Canada. See Ferguson, Remaking Liberalism: The Intellectual Legacy of Adam Shortt, O.D. Skelton, W.C. Clark and W.A. Mackintosh (Montreal: McGillQueen's University Press, 1993).

"It is contended here merely that the liberal view was prevalent. There is no claim at all that opposing points of view had ceased to exist or were not influential to some degree after 1918. Indeed, some of the so-called "Tory" outlooks of Innis, McLuhan, and Grant hark back to the earlier conservative tradition.

'Ferguson, Remaking Liberalism, 240.

${ }^{6}$ Doug Owram The Government Generation: Canadian Intellectuals and the State 1900-1945 (Toronto: University of Toronto Press, 1986), 133.

'Donald Creighton, Harold Adams Innis: Portrait of a Scholar (Toronto: University of Toronto Press, 1957), 81-2.

${ }^{8}$ E.J. Urwick to Harold Innis, 18 November 1940, Harold Innis Papers, University of Toronto Archives (UTA), B72-0025, Box 011, file 15. ${ }^{9}$ Creighton Portrait of a Scholar, 109.

"Harold Innis "Address to the President" (President H.J. Cody. No date - 1941), Harold Innis Papers, UTA, Box 005, file 18, B72-0003, 1. 
Note that Innis was fundamentally opposed to Underhill's view that the scholar should take up positions outside academia. He urged the scholar to remain in the ivory tower, a notion which conflicted with Underhill's ideas.

"Ibid.

${ }^{12}$ E.J. Urwick to Innis, 18 November 1940, Harold Innis Papers, UTA, B72-0025, Box 011 , file 15, and Urwick to Innis, 30 December 1942, Harold Innis Papers, UTA, B 72-0025, Box 01 1, file 15.

'Innis, "This Has Killed That," Journal of Canadian Studies 12 (5) (Winter 1977): 3.

${ }^{14}$ Ibid., 4.

"Arthur Lower, "The Social Sciences in the Post-War World," Canadian Historical Review 22 (March 1941): 108. Note, however, that unlike Innis, Lower was confident in the social scientist's traditional role to take an active part in public life and in consequence provide a check against the new state and protect against its abuse of social freedoms. In the end, the war represented both a period of great change and also an opportunity for Canada and its intellectuals; it was an opportunity for Canadian social scientists to impress their understandings and outlooks of the future on a young, emerging nation. He wrote: "A new order is struggling to be born among us, but in genetics as in other things we cling to laissez faire ideas, none of us knows much about [the new age]. The great problem [is] trying to divine the nature of the future, and as social scientists, perhaps even essaying to act as midwives." See ibid., 106 (my italics).

${ }^{16}$ Donald Creighton, "Memorandum for the Conference on American Thought," (no date, c.1944), Donald Creighton Papers, Public Archives of Canada (PAC), MG 31 D77, v. 1, General correspondence, 1944, \#2, 2.

${ }^{17}$ Creighton to John Marshall (Associate Director of the Humanities, The Rockefeller Foundation), 21 February 1944, v. 1, Donald Creighton Papers, PAC, MG 31 D77, General correspondence, 1944, $\# 2$.

${ }^{18}$ Grant to Mother, Easter [no date-1939?], George Parkin Grant Papers, PAC, MG 30 D59, v. 38; Mrs. W.L. Grant Correspondence; file: Queen's University, 1.

${ }^{19}$ The War Measures Act (WMA) was the operative instrument of the federal government's emergency power. The dominion government enacted 6,414 orders under the WMA. These order had the force of law and circumvented parliamentary debate. See Robert Bothwell, Ian Drummond, and John English, Canada Since 1945: Power, Politics and Provincialism, revised edition (Toronto: University of Toronto Press, 1989), 53. 
${ }^{20}$ The government brought war-related industries directly under its control. By war's end, 85 per cent of all non-agricultural labour fell under governmental authority. See ibid., 55.

21Ibid.,53.

22Ibid.

${ }^{23}$ The Federal Government was empowered to collect these taxes in 1947. In return, the provinces were to receive grants, based on complex formulae, designed to provide per capita grants and statutory subsidies. This system of grants was the genesis of transfer payments. Note that provinces of Ontario and Quebec established autonomous taxation systems. See ibid., 81.

${ }^{24}$ A.B. McKillop, Malters of Mind: The University in Ontario 17911951 (Toronto: University of Toronto Press, 1994), 521.

${ }^{25}$ Harold Innis, "A Plea for The University Tradition," Dalhousie Review 24(1944): 299-300.

${ }^{26}$ George Grant, "The Teaching of Philosophy in English-Speaking Canada," draft copy, (24 October 1950), Hilda Neatby Papers, University of Saskatchewan Archives (USA), II. 93; file: Grant, Professor G.P., "The Teaching of Philosophy in EnglishSpeaking Canada," 3. See also Grant, "Philosophy" in Canada," Royal Commission Studies: A Selection of Essays Prepared for the Royal Commission on National Development in the Arts, Letters and Sciences (Ottawa, 1948).

27Innis, "A Plea for The University Tradition," 299.

${ }^{23}$ Watson Kirkconnell and A.S.P. Woodhouse The Humanities in Canada (Ottawa: Humanities Research Council, 1947), 6-11.

${ }^{29}$ McKillop, Matters of Mind, 529; McKillop entitles a chapter of his recent work "The Culture of Utility."

${ }^{30}$ Grant, "The Teaching of Philosophy," 19.

"Ibid.

${ }^{32}$ H.A. Innis, "Charles Norris Cochrane, 1889-1946," Canadian Journal of Economics and Political Science 12 (1) (June 1929): 96.

${ }^{33}$ Carl Berger, The Writing of Canadian History: Aspects of English-Canadian Historical Writing Since 1900, second edition (Toronto: University of Toronto Press, 1986), 188.

${ }^{34}$ See Harold Innis, Empire and Communications, revised edition, (Toronto: University of Toronto Press, 1972).

"Innis, A Plea for Time, Sesquicentennial Lectures, (Fredericton: The University of New Brunswick, 1950), 11.

${ }^{36}$ Innis, The Strategy of Culture (Toronto: University of Toronto Press, 1952), 14.

${ }^{37}$ Innis, Empire and Communications, 9.

${ }^{38}$ Innis, The Bias of Communications (reprinted, Toronto: University of Toronto Press, 1964), 132.

${ }^{39}$ Ibid., 139.

40[bid., 33-34. 
4'Hutchins's work was well known in Canada, and he corresponded on cultural and educational issues with several Canadian scholars, including Innis and Hilda Neatby, .

${ }^{42}$ Claude Bissell, "Herbert Marshall McLuhan" in George Sanderson and Frank Macdonald, eds. Marshall McLuhan: The Man and his Message (Golden, CO:Fulcrum, 1989), 6.

${ }^{43}$ Philip Marchand, Marshall McLuhan: The Medium and the Messenger (Toronto: Random House, 1989), 47-49.

${ }^{4}$ Marshall McLuhan, The Mechanical Bride: The Folklore of Industrial Man (Boston: Beacon Press, 1951), 43. Hutchins and Mortimer Adler created a Great Books program at the University of Chicago. McLuhan objected to the "Greats" approach not because he did not advocate the study of important philosophical and literary works. To the contrary, he thought students ought to study the "Greats." He opposed the mechanical and artificial treatment of the important thinkers and writers, an approach he thought was intrinsic to the Great Books program.

4s Ibid., 44.

${ }^{46}$ McLuhan to Clement McNaspy, S.J., 15 Dec. 1945 [15 Jan. 1946?], Letters of Marshall McLuhan, eds. Matie Molinaro, Corrine McLuhan, and William Toye (Toronto: Oxford University Press, 1987), 180.

${ }^{47} \mathrm{McLuhan}$, The Mechanical Bride, 44.

${ }^{48}$ This rejection of the "Greats" approach and propensity to study the salient features of modern culture characterized McLuhan's shift from literary studies to his early work on the effects of technique. His first important book in this new field, The Mechanical Bride, was an effort to analyze the impact of the socalled "unofficial" education.

${ }^{49}$ Marshall McLuhan, "American Advertising," in Eric McLuhan and Frank Zingrone, eds., Essential McLuhan (Concord, ON: Anansi, 1995), 13; originally published as Marshall McLuhan, "American Advertising," Horizon (October 1947).

solbid., 14.

"Marshall McLuhan, "Education of Free Men in Democracy: The Liberal Arts," in St. Louis Studies in Honour of St. Thomas Aquinas (1943): 49.

s2Tbid., 50.

${ }^{33}$ Marshall McLuhan, "The Mechanical Bride," in Essential McLuhan, 21. Originally published as Marshall McLuhan, The Mechanical Bride: The Folklore of Industrial Man.

s4Ibid., 49.

ss Marshall McLuhan, The Mechanical Bride, 21.

s6Ibid., 33.

s7 Thid. 
selbid., 40.

${ }^{59}$ Ibid., 7.

${ }^{60}$ Ibid., 87.

${ }^{61}$ Kenneth Norrie and Doug Owram, A History of the Canadian Economy (Toronto: Harcourt Brace, 1991), 567.

${ }^{62}$ Vincent Massey , Canada Club, London, England, Dominion Day 1953, Draft Copy, Hilda Neatby Papers, USA, A139, L.12, Massey, Vincent, 1951-1969, (1), 2. See also "Canada: Her Status and Stature" in Vincent Massey, Speaking of Canada: Addresses by the Right Honourable Vincent Massey (Toronto: Macmillian of Canada, 1959), 3-6.

${ }^{63}$ Vincent Massey, "Useful Knowledge," Convocation of the University of Manitoba, Draft Copy, Hilda Neatby Papers, USA, A139, I.12, Massey, Vincent, 1951-1969, (2), 4. See also "Useful Knowledge" in Massey, Speaking of Canada.

${ }^{64}$ Harold Innis, "Implications of the Interactions Between Values and Resources" (unpublished address, 2 October 1949), Harold Innis Papers, UTA, B72-003, Box 20, file 33, 1.

${ }^{65}$ Ibid., 9.

${ }^{66}$ Innis to Arthur Cole, 20 January 1950, Harold Innis Papers, UTA, B 72 - 0025; 011, 01. Note also that the Innis's "plea for time" and Massey's concern for the demise of spiritual values were reflected on the minds of many others in the post-war generation of Canadian social critics. Historian Hilda Neatby railed against "the age of scientific materialism" because it overemphasized the present at the expense of the historical, cultural, and religious tradition of the West. See Neatby, "Special Study on Canadian History," Draft Copy, Hilda Neatby Papers, USA, A139, II. 103, Special Studies: Neatby, Hilda, "Special Study on Canadian History," 21-2. A "crisis of values" was also reflected in the Massey Commission and in educators' concern over the fate of the humanities in the post-war period.

${ }^{67}$ George M. Grant, "Thanksgiving and Retrospect," Queen's Quarterly 9(3)(January 1902):231, quoted in Owram, The Government Generation, 15.

"BIbid., 15-16.

${ }^{69}$ George Grant, "The Uses of Freedom," Queen's Quarterly 62 (Winter 1955-6), 518.

${ }^{70}$ Tbid.

"Ibid., 521.

"7lbid., 520-1.

${ }^{7}$ Ibid., 521.

${ }^{74}$ George Grant, Technology and Empire. Perspectives on North America (Toronto: Anansi, 1969), 137.

${ }^{75}$ Ibid., 28. 
${ }^{76}$ Kroker, Technology and the Canadian Mind, 18-19.

"Quoted in William Christian, George Grant: A Biography (Toronto: University of Toronto Press, 1993), 143.

${ }^{78}$ Grant, "The Teaching of Philosophy," 7.

79lbid.

${ }^{80}$ Ibid., 5-6.

${ }^{81} \mathrm{Grant}$ here refers to the efforts of the Massey Commission and scholars, such as C.N. Cochrane and Harold Innis, to pursue a philosophical approach to modern humanity's problems.

${ }^{82}$ Grant, "The Teaching of Philosophy," 8.

sIbid.

"George Grant, Philosophy in the Mass Age (Toronto: Copp Clark, 1959), 7-8.

${ }^{85}$ Grant, Technology and Empire, 88-9.

${ }^{86}$ Ibid., 19.

${ }^{87}$ Paul Litt, The Muses, the Masses, and the Massey Commission (Toronto: University of Toronto Press, 1992), 3.

${ }^{83}$ Massey indicated time and again that he had nothing against "Jowbrow" culture per se. He even took pains to avoid using the term. It was the loss of a Canadian cultural identity at the hands of American mass culture that was repugnant to the Massey commissioners. See Litt, as well as Massey, Speaking of Canada.

${ }^{89} \mathrm{Canada}$, Royal Commission on National Development in the Arts, Letters and Sciences, Report (Ottawa: Edmond Cloutier, 1951), 272.

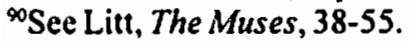

'Ibid., 36.

"Note, however, that Grant submitted his "'Philosophy' in Canada" to the Massey Commission for publication in 1948. 